\title{
Fungicidal Potential of Allelopathic Weed Cenchrus pennisetiformis ON GROWTH OF Fusarium oxysporum f. sp. lycopersici UNDER CHROMIUM STRESS ${ }^{1}$
}

\author{
Potencial Fungicida de Grama Alelopática Cenchrus pennisetiformis no Crescimento de \\ Fusarium oxysporum f. sp. lycopersici sob Estresse de Cromo
}

\author{
KHURSHID, S. ${ }^{2}$, SHOAIB, A. ${ }^{2}$, JAVAID, A. ${ }^{2}$, and QAISAR, U. ${ }^{3}$
}

\begin{abstract}
The present study was conducted to assess antifungal potential of the allelopathic grass Cenchrus pennisetiformis Hochst. \& Steud. against the fungal plant pathogen Fusarium oxysporum f. sp. lycopersici (cause of tomato wilt disease) under chromium stress. Laboratory experiments were performed in $10 \mathrm{~mL}$ volume glass test tubes each containing $1.0 \mathrm{~mL}$ of malt extract broth with seven concentrations $(0,50,100,150,200,250,300$ and $350 \mathrm{ppm}$ ) of each of $\mathrm{Cr}(\mathrm{III})$ and $\mathrm{Cr}(\mathrm{VI})$, and two concentrations (5\% and $6 \%$ ) of methanolic leaf, stem or root extract of $C$. pennisetiformis. A metal + weed extract amended medium was inoculated with the pathogen and incubated for 7 days at $25 \mathrm{C}$. Different concentrations of $\mathrm{Cr}(\mathrm{III})$ and $\mathrm{Cr}(\mathrm{VI})$ proved equally inhibitory resulting in $10-84 \%$ and $18-89 \%$ reduction in fungal biomass, respectively. Methanolic leaf, stem and root extracts of the weed reduced fungal biomass by $12-25 \%, 14-23 \%$ and $46-50 \%$, respectively, over negative control. In combined application of methanolic extracts of different parts of C. pennisetiformis and metal solutions, root extract in combination with either $\mathrm{Cr}(\mathrm{III})$ or $\mathrm{Cr}$ (VI) showed the highest inhibitory potential against the fungus followed by leaf and stem extracts. In combination with methanolic root, leaf and stem extracts, different concentrations of $\mathrm{Cr}$ (III) and $\mathrm{Cr}$ (VI) significantly reduced fungal biomass by 54-99\%, 14-99\% and 9-95\%, respectively, over negative control. Such studies have not been carried out previously. Results of the present investigation suggest that $F$. oxysporum oxysporum f. sp. lycopersici, the cause of Fusarium wilt disease in tomato, can be managed by application of extracts (or alternatively biomass) of C. pennisetiformis in chromium contaminated soils.
\end{abstract}

Keywords: grass, heavy metal, Poaceae, wilt pathogen.

RESUMO - O presente estudo foi conduzido para avaliar o potencial antifúngico da grama alelopática Cenchrus pennisetiformis Hochst. \& Steud. contra o fungo patógeno de plantas Fusarium oxysporum $f$. sp. lycopersici (causador da doença murcha-de-fusário) sob estresse de cromo. Experimentos laboratoriais foram realizados em tubos de ensaio de vidro com volume de $10 \mathrm{~mL}$, cada um contendo 1,0 mL de extrato de caldo de malte em sete concentrações (50, 100, 150, 200, 250, 300 e 350 ppm), para cada Cr(III) e Cr(VI), e duas concentrações de extrato de folha, caule ou raiz metanólica (5\% e 6\%) de C. pennisetiformis. Um meio alterado de metal + extrato de grama foi inoculado com o patógeno e incubado por sete dias em uma temperatura de $25^{\circ} \mathrm{C}$. Concentrações diferentes de Cr(III) e CR(VI) demonstraram resultados igualmente inibitórios em reduções de 10$84 \%$ e 18-89\% na biomassa do fungo, respectivamente, em relação ao controle. Extratos metanólicos de folha, caule e raiz de grama reduziram a biomassa do fungo em 12-25\%, 14-23\% e 46-50\%, respectivamente, quando comparados ao controle. Em aplicações combinadas de extratos metanólicos de partes diferentes de C. pennisetiformis e soluções metais, extratos de raiz combinados tanto com Cr(III) quanto com Cr(VI) mostraram os maiores potenciais inibitórios contra o fungo, seguidos pelos extratos de folha e caule. Na combinação com extratos metanólicos de raiz, folha e caule, concentrações diferentes de Cr(III) e Cr(VI) reduziram significativamente a biomassa do fungo em 59-99\%, 14-99\% e 9-95\%, respectivamente, comparando-se ao controle. Esses estudos não foram

Recebido para publicação em 6.3.2016 e aprovado em 1.4.2016.

2 Institute of Agricultural Sciences, University of the Punjab, Lahore, Pakistan.<aamnaa29@yahoo.com>. ${ }^{3}$ School of Biological Sciences, University of the Punjab, Lahore, Pakistan. 
realizados anteriormente. Os resultados desta pesquisa sugerem que $\boldsymbol{F}$. oxysporum $f$. sp. lycopersici, causador da murcha-do-fusário em tomates, pode ser manejado pela aplicação de extratos (ou, alternativamente, biomassa) de C. pennisetiformis em solos contaminados com cromo.

Palavras-chave: grama, metal pesado, Poaceae, patógeno de murcha.

\section{INTRODUCTION}

Chromium $(\mathrm{Cr})$ is an important multipurpose metal extensively utilized in different industries including metallurgy, refectory, plating, tannery, wood preservation and pigment manufacturing etc. $\mathrm{Cr}(\mathrm{III})$ and $\mathrm{Cr}(\mathrm{VI})$ are the two most stable oxidation forms of $\mathrm{Cr}$ in the environment (Smith et al., 2002). $\mathrm{Cr}$ (III) mainly exists as hydroxides, oxides or sulphates and small amounts of it are vital for humans, animals and microorganisms. However, its essentiality for plants is debatable (Sharma et al., 2003). The divalent oxyanions of $\mathrm{Cr}$ (VI) (such as $\mathrm{CrO}_{4}^{-2}$, or $\mathrm{Cr}_{2} \mathrm{O}_{7}^{-2}$ ) are 100 to 1,000 times more toxic, more soluble in water and more motile and strong oxidizing agent than $\mathrm{Cr}$ (III) (Iqbal et al., 2011). Therefore, $\mathrm{Cr}(\mathrm{VI})$ has been declared lethal for all living beings (Cardenas-Gonzalez and AcostaRodrýguez, 2010). So far, it is imperative to assess the impact of both oxidation states of chromium metallic ions on the growth of microorganisms including fungi (Kurshied et al., 2014). Fungi have been reported to cause over $70 \%$ of plant diseases. Such fungal phytopathogens exhibit potential to accumulate heavy metals as well. It has also been documented that growth, sporulation and pathogenicity of fungi are considerably limited by some heavy metal ions, especially at high concentrations (Jaworska and Gorczycaa, 2004). However, variation in spectrum of interaction between fungi and heavy metal has been reported (Kurshied et al., 2014). Many fungal species of the genera Alternaria, Fusarium, Trichoderma, Fusarium, Aspergillus and Penicillium are enlisted as metal-tolerant fungi (Nazina et al., 2002). Tkaczuk (2005) reported that strong pollution of soil by $\mathrm{Cr}^{3+}$ could be a restrictive factor for development and pathogenicity of fungi in the environment. In contrast, Hasan (2007) found significant growth improvement of $F$. oxysporum under $\mathrm{Cd}^{2+}, \mathrm{Mn}^{2+}$ and $\mathrm{Zn}^{2+}$ stress.
Fusarium oxysporum f. sp. lycopersici (Sacc.) Snyd \& Hans, pathogen of Fusarium wilt is a soil-borne fungus that damages field and greenhouse-grown tomato plants globally in warmer areas (Abdel-Monaim, 2012). The fungus grows preferentially at $28-29{ }^{\circ} \mathrm{C}$ in dry soil and the proliferation of the pathogen inside the plant is favored by moist soil (Nelson et al., 1981). Seedlings infected by this fungus show yellowing of the lower leaves, often only on one side of the plant followed by reduced growth and eventually death of entire plant (Kumar et al., 2008). Control of wilt diseases of tomato depends mainly on chemical pesticides. However, chemical control for soil-borne diseases is usually unsuccessful due to high tolerance of wilt pathogens in diverse environments and having extremely wide host range. In addition, due to health and environmental risks associated with the use of synthetic chemicals, scientists are focusing on alternate cultural and biological options for disease management like field sanitation, crop rotation, bioactive compounds extracted from antagonistic fungi, bacteria or allelopathic plants and use resistant varieties (Javaid and Rauf, 2015).

Plant products may serve as a novel alternative source of pesticides to overcome fungal diseases under metal-stressed conditions along with metal remediation potential (Prasad, 2012). Antimicrobial activity of extracts, oils or volatile materials of many plant species including weeds has been well documented (Iqbal and Javaid, 2012). Cenchrus pennisetiformis is a summer growing, drought tolerant, and extremely valuable perennial fodder grass of Poaceae found predominantly in the world vegetation (Hall, 2008). This genus has 22 species in tropical and warm temperate regions of Africa and America; while 5 species occur in Pakistan (www.eflora.org). Various Cenchrus spp. have variations in contents of malondialdehyde, proline, and carbon isotope that classified these as potential biological control agent (Chandra and Dubey, 2010). Few 
preliminary studies conducted so far revealed that extract of C.pennisetiformis has antifungal and herbicidal potential (Shafique et al., 2004; Javaid et al., 2006). However, simultaneous impact of metal stress and plant extract on pathogen growth needs to be explored. The present study was, therefore, planned to study antifungal activity of methanolic extracts of different parts of C. pennisetiformis for management of $F$. oxysorum under abiotic stress of chromium.

\section{MATERIALS AND METHOD}

Isolation, culturing and identification of F. oxysporum f. sp. lycopersici (FOL): $F$. oxysporum f. sp. lycopersici was aseptically isolated from roots of tomato plants suffering from wilt disease. The fungus was sub-cultured and maintained on a pantachloronitrobenzene (PCNB) agar medium and identified on the basis of morphological characters (Ignjatov et al., 2012).

Preparation of metal solutions: $\mathrm{Cr}$ (III) and $\mathrm{Cr}(\mathrm{VI})$ stock solutions were prepared by dissolving $2.82 \mathrm{~g}$ of potassium dichromate $\left(\mathrm{K}_{2} \mathrm{Cr}_{2} \mathrm{O}_{7}\right)$ and $7.69 \mathrm{~g}$ of chromium nitrate $\left[\mathrm{Cr}\left(\mathrm{NO}_{3}\right)_{3} .9 \mathrm{H}_{2} \mathrm{O}\right]$ (Merk, Germany in $1,000 \mathrm{~mL}$ of double distilled water, respectively. Further dilutions of 50,100,150, 200, 250, 300 and $350 \mathrm{ppm}$ were made with distilled water to make final volume $48 \mathrm{~mL}$ of each metal concentration of each of the two salts. Malt extract $(0.6 \mathrm{~g})$ was added in each $6 \mathrm{~mL}$ metal aliquots in pre-sterilized glass test tubes. Tubes were sealed with sterilized cotton plugs and autoclaved.

Preparation of methanolic extract: Crushed dried root, stem and leaf materials of C. pennisetiformis (200 g each) were soaked in methanol for 14 days. Afterwords, the soaked materials were passed through cheese cloths to separate debris. Filtrates were filtered through Whatman No. 1 paper filter and methanol was evaporated on a rotary evaporator at $45^{\circ} \mathrm{C}$.

Laboratory bioassays: There were two sets of treatments. In the first set, different concentrations of $\mathrm{Cr}$ (III) were separately combined with $5 \%$ and $6 \%$ concentrations of methanolic leaf, stem and root extracts of
C. pennisetiformis. Malt extract at $2 \mathrm{~g} 100 \mathrm{~mL}^{-1}$ of different concentrations of $\mathrm{Cr}$ (III) was added and autoclaved at $121 \mathrm{C}$ and $103 \mathrm{kPa}$ pressure for 30 minutes. The medium was cooled and appropriate quantities of methanolic extracts of different parts of C. pennisetiformis were added to achieve $5 \%$ and $6 \%$ final concentrations of these extracts in the growth medium. In a similar way, the growth medium in the second set of treatments was prepared by using solutions of different concentrations of $\mathrm{Cr}(\mathrm{VI})$. Different concentrations of $\mathrm{Cr}$ (III) and $\mathrm{Cr}(\mathrm{VI})$ were also used without addition of methanolic extracts to serve as control. Both sets of the bioassays were carried out in $5 \mathrm{~mL}$ volume test tubes each containing $1.0 \mathrm{~mL}$ growth medium. Each treatment was replicated three times. Tubes were inoculated with $15 \mu \mathrm{L}$ conidial suspension of $F$. oxysporum f. sp. lycopersici and incubated at $28 \pm 2 \mathrm{C}$ for 7 days. Thereafter, materials were filtered using pre-weighed paper filters, dried at $70{ }^{\circ} \mathrm{C}$ and weighed. All the data were analyzed by analysis of variance followed by Tukey's HSD test using computer the software Statistics 8.1. The relationship between $\mathrm{Cr}$ (III) $\mathrm{Cr}$ (VI) concentrations and fungal biomass was calculated by using MS Excel.

\section{RESULTS AND DISCUSSION}

There was a significant reduction of $10-83 \%$ in fungus growth due to different concentrations (50-350 ppm) of $\mathrm{Cr}$ (III) over negative control (without $\mathrm{Cr}$ ions or plant extracts). When leaf, stem and root extracts of C. pennisetiformis were added in the growth medium combined with different concentrations of $\mathrm{Cr}(\mathrm{III})$, the reduction of fungal biomass was more pronounced with root extract. Whereas, $6 \%$ concentrations of all the extracts showed a more significant reduction in fungal biomass than $5 \%$ concentrations. The fungal biomass was significantly declined by $24-88 \%, 23-83 \%, 57-98 \%$ due to $5 \%$ and by $40-90 \%, 40-88 \%$ and $65-99 \%$ due to $6 \%$ concentration of leaf, stem and root extracts in combination with different concentration (50-350 ppm) of $\mathrm{Cr}$ (III), respectively, over the negative control. The leaf, stem and root extracts of $C$. pennisetiformis alone significantly inhibited fungal biomass by $12 \%, 14 \%$ and $45 \%$ due to $5 \%$ and by $25 \%, 22 \%$ and $50 \%$ due to $6 \%$ 
concentration, respectively, as compared to negative control. However, methanolic extract of leaf, stem and root in combination with different concentrations (50-350 ppm) of $\mathrm{Cr}$ (III) considerably reduced fungal biomass by $2-86 \%$, $2-81 \%$ and $17-96 \%$ due to $5 \%$ and $14-86 \%$, $5-85 \%$ and $20-98 \%$ due to $6 \%$ concentrations, respectively over their corresponding methanolic extracts control treatments. Whereas, 5\% concentration of leaf, stem and root extract in combination with different concentrations of $\mathrm{Cr}$ (III) suppressed the fungal biomass by $12-28 \%, 0-26 \%$ and $45-86 \%$, respectively as compared to corresponding metal concentration alone. While, the fungal biomass was decreased by $30-50 \%, 10-40 \%$ and $50-94 \%$ due to simultaneous effect of $6 \%$ concentration of leaf, stem and root extract, respectively and different concentrations of $\mathrm{Cr}(\mathrm{III})$, respectively over corresponding metal concentration alone (Figure 1 and 2, Table 1).

When the fungus was grown in growth medium containing different concentrations (50-350 ppm) of $\mathrm{Cr}(\mathrm{VI})$, its growth was significantly declined by $18-89 \%$ in comparison to negative control. $\mathrm{Cr}(\mathrm{VI})$ was proved slightly more toxic to fungal growth than $\mathrm{Cr}(\mathrm{III})$. Lower
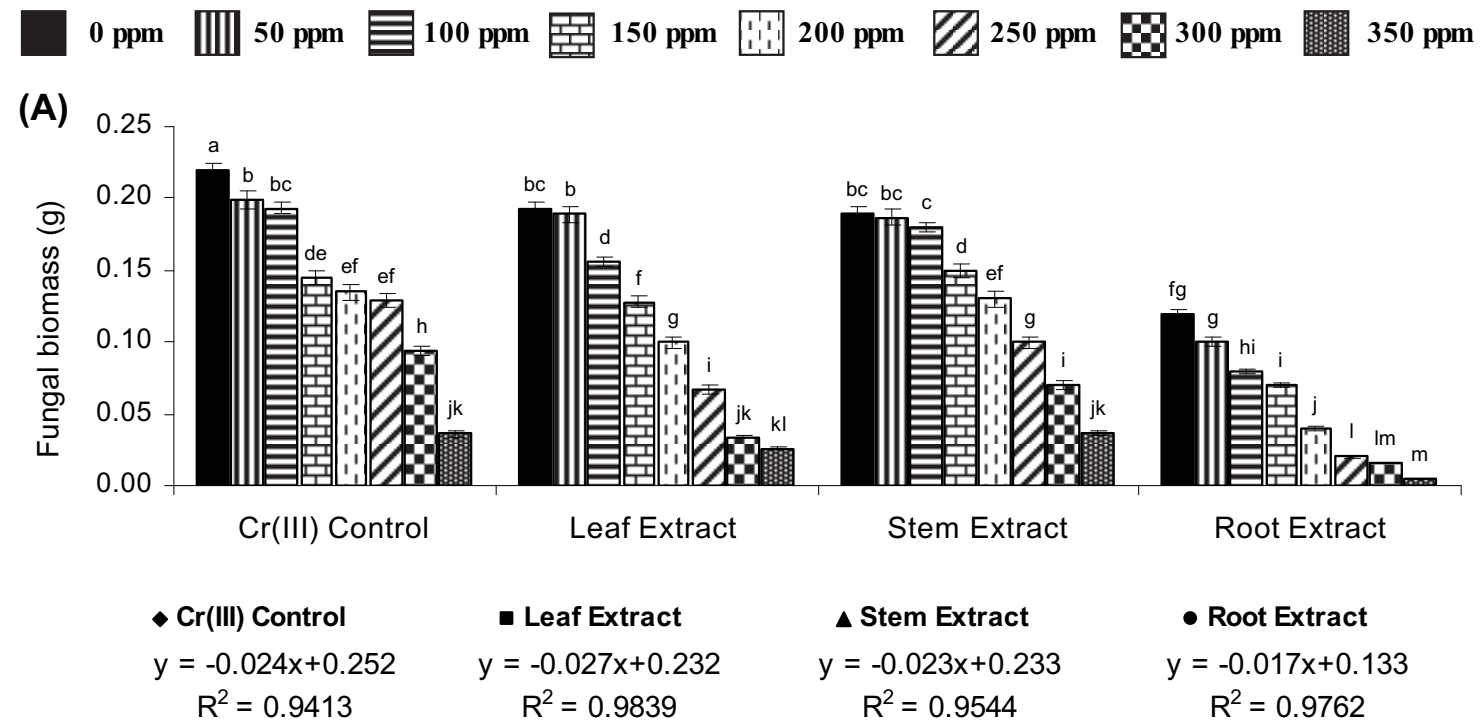

- Root Extract

$y=-0.017 x+0.133$

$\mathrm{R}^{2}=0.9762$

(B)

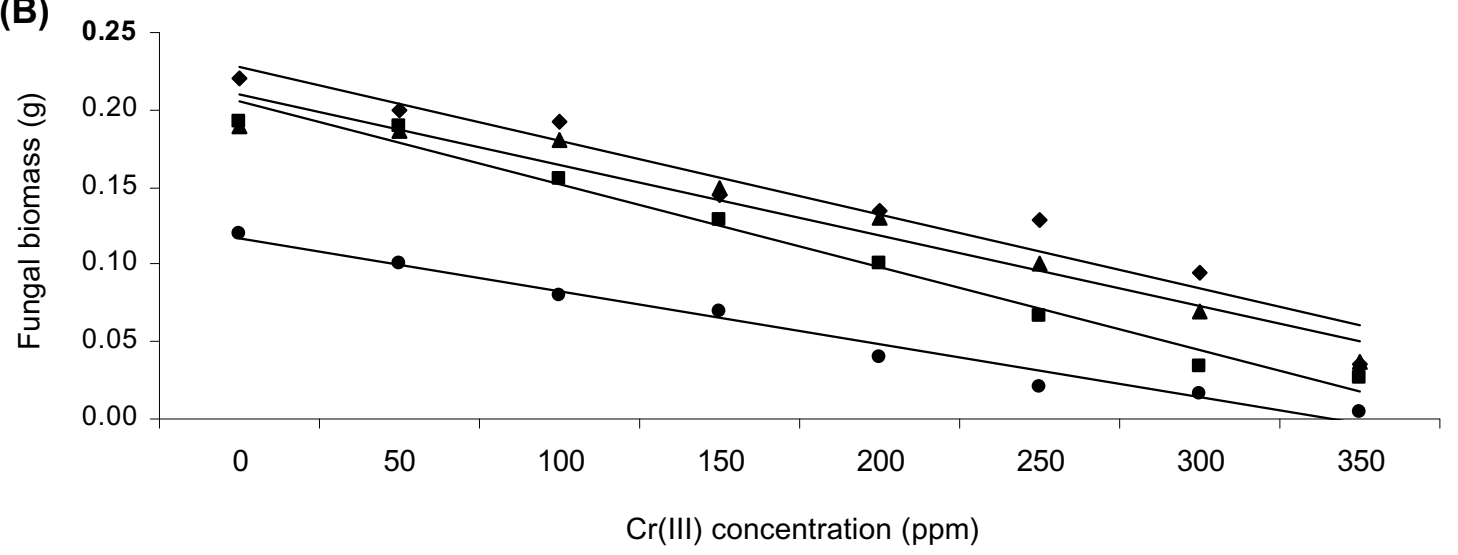

(A) Effect on fungal biomass; (B) Regression analysis for the relationship between different concentrations of Cr(III) (along with $5 \%$ leaf, stem and root extracts of $C$. penisetiformis) and biomass of FOL. Vertical bars show standard errors of means. Values with different letters at their top show significant difference $(\mathrm{p} \leq 0.05)$ as determined by Tukey's HSD Test.

Figure 1 - Effect of different concentrations of $\mathrm{Cr}(\mathrm{III})$ and 5\% methanolic leaf, stem and root extracts of Cenchrus pennisetiformis on biomass of Fusarium oxysporum f. sp. lycopersici (FOL). 

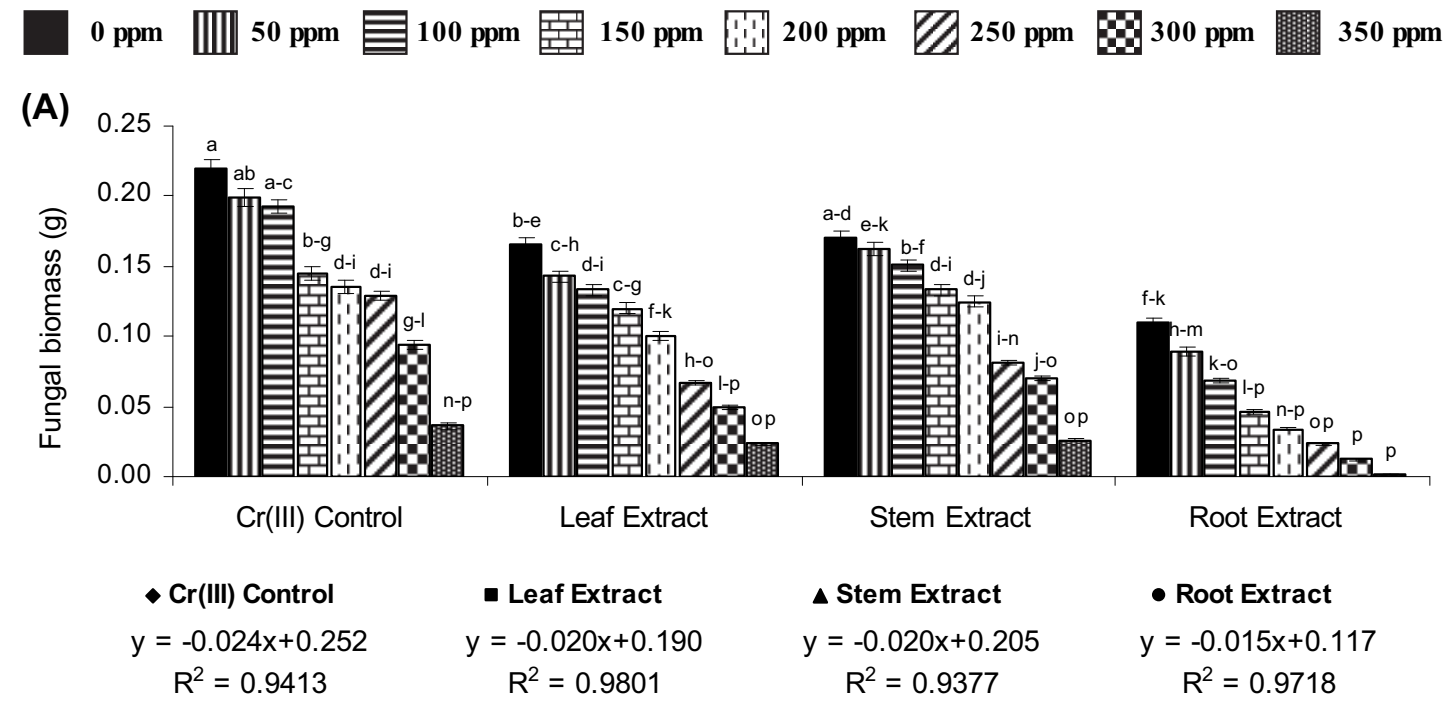

(B)

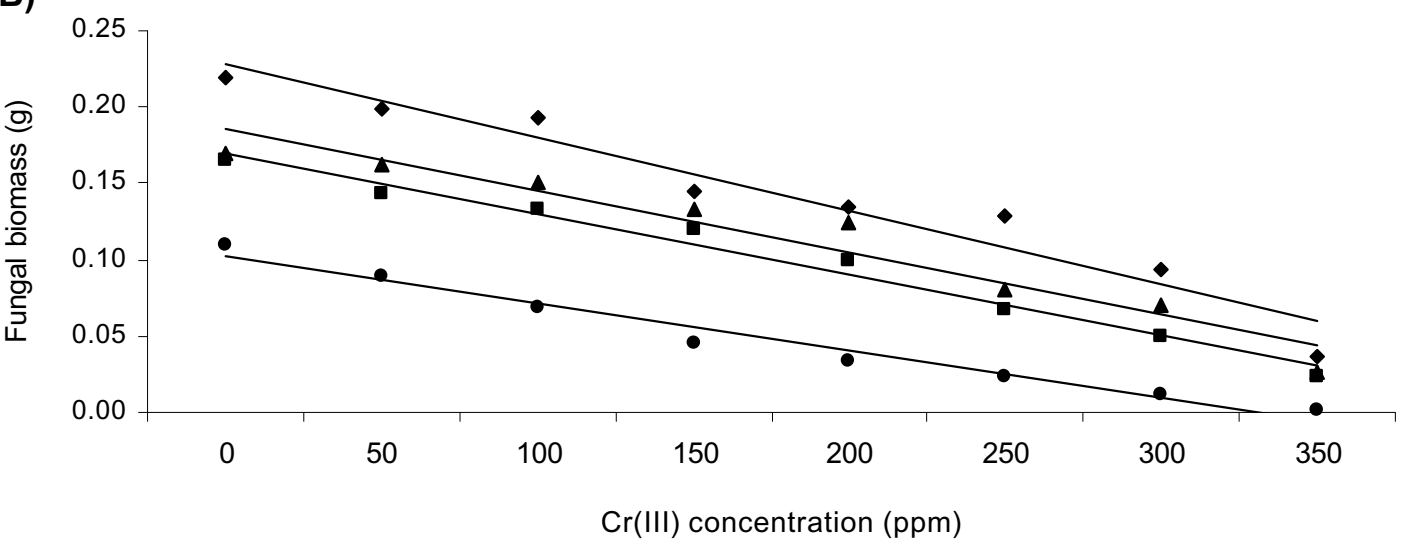

(A) Effect on fungal biomass; (B) Regression analysis for the relationship between different concentrations of Cr(III) (along with 6\% leaf, stem and root extracts of C. pennisetiformis) and biomass of FOL. Vertical bars show standard errors of means. Values with different letters at their top show significant difference $(\mathrm{p} \leq 0.05)$ as determined by Tukey's HSD Test.

Figure 2 - Effect of different concentrations of $\mathrm{Cr}(\mathrm{III})$ and $6 \%$ methanolic leaf, stem and root extracts of Cenchrus pennisetiformis on biomass of Fusarium oxysporum f. sp. lycopersici (FOL).

concentration $(5 \%)$ of methanolic leaf and stem extracts along with different concentrations of $\mathrm{Cr}(\mathrm{VI})$ suppressed fungal biomass by $24-90 \%$ and $23-86 \%$, respectively, over negative control. However, $5 \%$ extract of root along with seven concentrations of $\mathrm{Cr}(\mathrm{VI})$ showed significant reduction of $57-99 \%$ in fungal biomass in contrast to negative control. In case of $6 \%$ extracts of leaf, stem and root along with different concentrations of $\mathrm{Cr}(\mathrm{VI})$, there was significant decline of 39-99\%, 36-94\% and $65-99 \%$ in fungal biomass over negative control. The fungal biomass was significantly decreased by $12 \%, 14 \%$ and $45 \%$ due to $5 \%$ concentration and $25 \%, 22 \%$ and $50 \%$ due to $6 \%$ concentration of leaf, stem and root extracts as compared to negative control. When the two different concentrations of the three extract were mixed with seven different concentrations of $\mathrm{Cr}(\mathrm{VI})$, biomass of the fungus was reduced up to $99 \%$ in comparison to their respective methanolic extract control treatment. When combined effect of plant extract and different concentration of $\mathrm{Cr}(\mathrm{VI})$ was assessed against their corresponding metal concentrations, inconsistent variation in fungal biomass were observed. The $5 \%$ concentration of leaf and stem extracts either increased fungal biomass by $1-30 \%$ or decreased by $2-40 \%$ over 
Table 1 - Percentage of the decrease in fungal biomass due to separate and combined application of Cr(III) and methanolic extracts of Cenchrus pennisetiformis

\begin{tabular}{|c|c|c|c|c|c|}
\hline Treatment & $\begin{array}{l}\mathrm{Cr} \text { (III) conc. } \\
\quad(\mathrm{ppm})\end{array}$ & $\begin{array}{c}\text { Extract conc. } \\
(\%)\end{array}$ & $\begin{array}{c}\text { Decrease over } \\
\text { negative control } \\
(\%)\end{array}$ & $\begin{array}{c}\text { Decrease over } \\
\text { corresponding } \\
\text { methanolic extracts } \\
(\%)\end{array}$ & $\begin{array}{c}\text { Decrease over } \\
\text { corresponding } \\
\text { metal (alone) } \\
\text { concentration }(\%)\end{array}$ \\
\hline \multirow{8}{*}{$\mathrm{Cr}$ (III) } & 0 & 0 (-control) & - & - & - \\
\hline & 50 & 0 & 10 & - & - \\
\hline & 100 & 0 & 12 & - & - \\
\hline & 150 & 0 & 34 & - & - \\
\hline & 200 & 0 & 39 & - & - \\
\hline & 250 & 0 & 41 & - & - \\
\hline & 300 & 0 & 57 & - & - \\
\hline & 350 & 0 & 83 & - & - \\
\hline \multirow{16}{*}{ Leaf extract } & 0 & 5 & 12 & - & 12 \\
\hline & 50 & 5 & 14 & 2 & 5 \\
\hline & 100 & 5 & 29 & 20 & 19 \\
\hline & 150 & 5 & 42 & 34 & 12 \\
\hline & 200 & 5 & 55 & 47 & 26 \\
\hline & 250 & 5 & 70 & 65 & 48 \\
\hline & 300 & 5 & 85 & 83 & 64 \\
\hline & 350 & 5 & 88 & 86 & 28 \\
\hline & 0 & 6 & 25 & - & 25 \\
\hline & 50 & 6 & 35 & 14 & 28 \\
\hline & 100 & 6 & 40 & 20 & 31 \\
\hline & 150 & 6 & 45 & 28 & 20 \\
\hline & 200 & 6 & 55 & 40 & 26 \\
\hline & 250 & 6 & 70 & 60 & 48 \\
\hline & 300 & 6 & 78 & 70 & 47 \\
\hline & 350 & 6 & 90 & 86 & 36 \\
\hline \multirow{16}{*}{ Stem extract } & 0 & 5 & 14 & - & 14 \\
\hline & 50 & 5 & 15 & 2 & 6 \\
\hline & 100 & 5 & 18 & 5 & 7 \\
\hline & 150 & 5 & 42 & 21 & -3 \\
\hline & 200 & 5 & 41 & 35 & 4 \\
\hline & 250 & 5 & 55 & 47 & 22 \\
\hline & 300 & 5 & 68 & 63 & 26 \\
\hline & 350 & 5 & 83 & 81 & -3 \\
\hline & 0 & 6 & 23 & - & 23 \\
\hline & 50 & 6 & 26 & 5 & 18 \\
\hline & 100 & 6 & 32 & 11 & 22 \\
\hline & 150 & 6 & 45 & 21 & 8 \\
\hline & 200 & 6 & 43 & 27 & 7 \\
\hline & 250 & 6 & 63 & 53 & 37 \\
\hline & 300 & 6 & 68 & 60 & 26 \\
\hline & 350 & 6 & 88 & 85 & 28 \\
\hline \multirow{16}{*}{ Root extract } & 0 & 5 & 46 & - & 45 \\
\hline & 50 & 5 & 55 & 17 & 50 \\
\hline & 100 & 5 & 64 & 33 & 58 \\
\hline & 150 & 5 & 68 & 42 & 52 \\
\hline & 200 & 5 & 82 & 67 & 70 \\
\hline & 250 & 5 & 91 & 83 & 85 \\
\hline & 300 & 5 & 93 & 87 & 83 \\
\hline & 350 & 5 & 98 & 96 & 86 \\
\hline & 0 & 6 & 50 & - & 50 \\
\hline & 50 & 6 & 60 & 20 & 55 \\
\hline & 100 & 6 & 69 & 40 & 65 \\
\hline & 150 & 6 & 79 & 60 & 68 \\
\hline & 200 & 6 & 85 & 70 & 75 \\
\hline & 250 & 6 & 90 & 80 & 82 \\
\hline & 300 & 6 & 94 & 90 & 87 \\
\hline & 350 & 6 & 99 & 98 & 94 \\
\hline
\end{tabular}

- Sign indicates increase in fungal biomass. 
corresponding metal concentration. However, $5 \%$ concentration of root extract along with different concentrations $(50-350 \mathrm{ppm})$ of $\mathrm{Cr}(\mathrm{VI})$ consistently decreased fungal biomass by $45-92 \%$, that of $6 \%$ of each of leaf, stem and root reduced fungal biomass by 26$92 \%, 23-45 \%$ and $60-95 \%$, respectively over corresponding metal concentration (Figure 3 and 4, Table 2).

The $50 \%$ growth of $F$. oxysporum in medium incorporated with 50-250 ppm of either $\mathrm{Cr}(\mathrm{III})$ or $\mathrm{Cr}(\mathrm{VI})$ exhibits its metaltolerant behavior and thereafter reduction and absence of growth indicated toxic effect of the metal (Amatussalam et al., 2011). Impairment of cell function and loss of cell integrity due to internalization of the metal in the cytosol likely to cause reduction in fungal biomass (Pal et al., 2010). Absence of fungal growth at the highest metal ions concentrations could be attributed to non-sporulation under extreme toxicity level or prolongation of lag phase (Anahid et al., 2011). More harmfulness of hexavalent than trivalent $\mathrm{Cr}$ to $F$. oxysporum could be due to essentiality of $\mathrm{Cr}$ (III) for microorganisms in minute amounts whereas no machinery is available for $\mathrm{Cr}(\mathrm{VI})$ hydrolysis in fungi. $\mathrm{Cr}(\mathrm{VI})$ toxicity was reported to link with its specific antagonism to sulfate uptake,

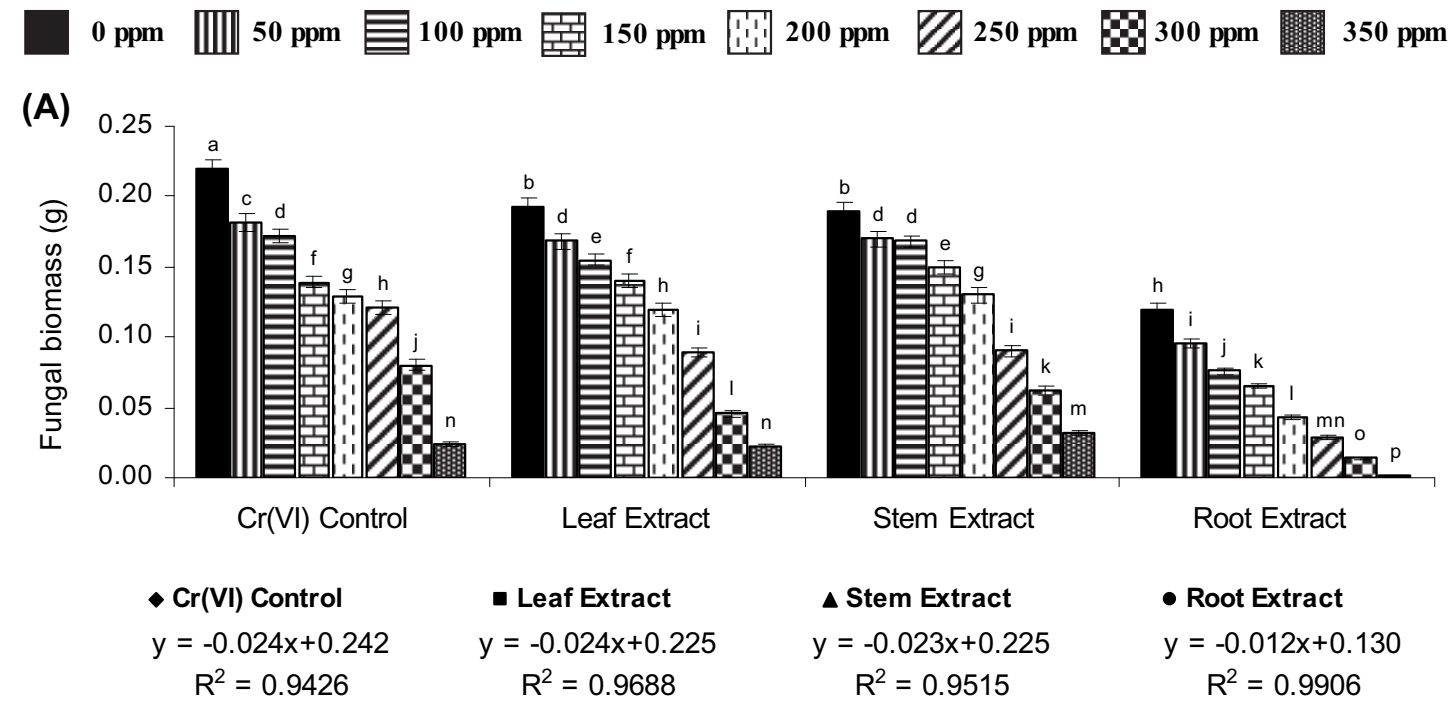

(B)

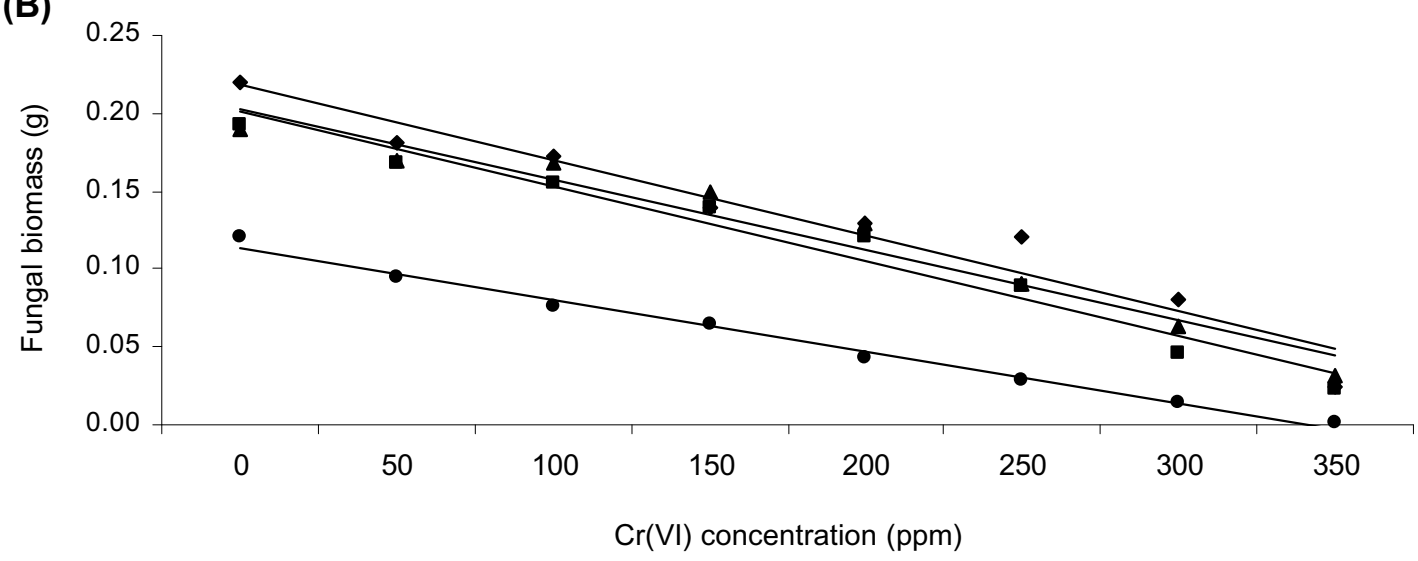

(A) Effect on fungal biomass; (B) Regression analysis for the relationship between different concentrations of Cr(VI) (along with 5\% leaf, stem and root extracts of C. pennisetiformis) and biomass of FOL. Vertical bars show standard errors of means. Values with different letters at their top show significant difference $(\mathrm{p} \leq 0.05)$ as determined by Tukey's HSD Test.

Figure 3 - Effect of different concentrations of $\mathrm{Cr}(\mathrm{VI})$ and 5\% methanolic leaf, stem and root extracts of Cenchrus pennisetiformis on biomass of Fusarium oxysporum f. sp. lycopersici (FOL). 


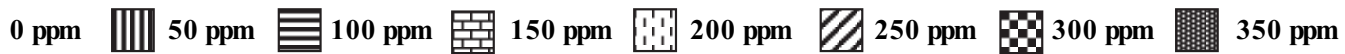

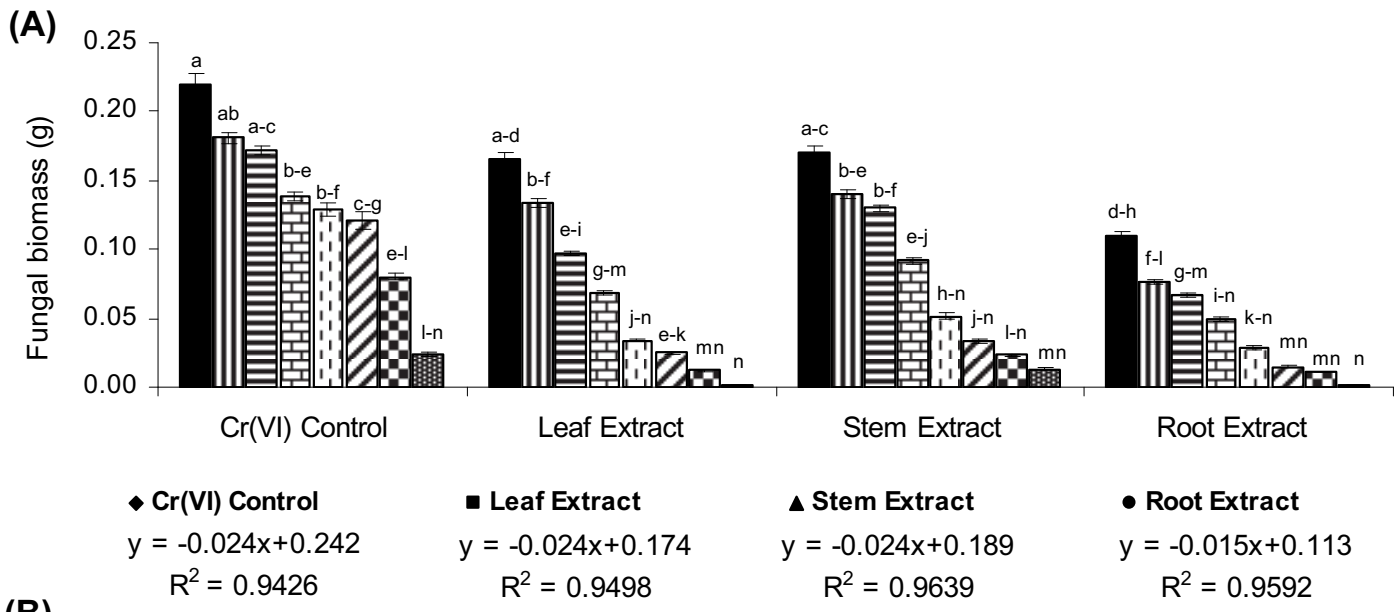

(B)

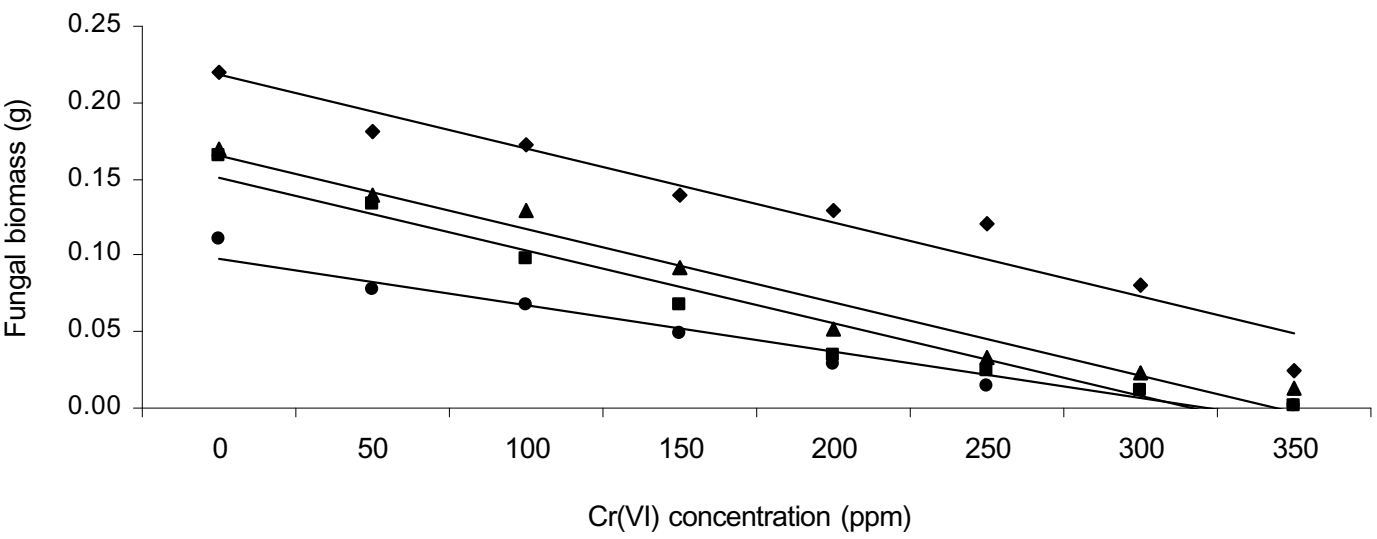

(A) Effect on fungal biomass; (B) Regression analysis for the relationship between different concentrations of $\mathrm{Cr}(\mathrm{VI})$ (along with 6\% leaf, stem and root extracts of C. pennisetiformis) and biomass of FOL. Vertical bars show standard errors of means. Values with different letters at their top show significant difference $(\mathrm{p} \leq 0.05)$ as determined by Tukey's HSD Test.

Figure 4 - Effect of different concentrations of $\mathrm{Cr}(\mathrm{VI})$ and $6 \%$ methanolic leaf, stem and root extracts of Cenchrus pennisetiformis on biomass of Fusarium oxysporum f. sp. lycopersici (FOL).

because $\mathrm{Cr}(\mathrm{VI})$ oxyanions have high homology with the fungus sulphate ions. Sulfate can serve as an electron acceptor in anaerobic respiration and can also be reduced for the formation of organic compound in fungi. It is stated that $\mathrm{Cr}$ transported into the cell by sulphate permease, and promotes three-step sulphate reduction, which cause higher toxicity to the fungal cells by formation of reactive oxygen species in the cell (Raspor et al., 2003). Whereas $\mathrm{Cr}$ (III) toxicity resulted from antagonism with iron transport (Ramana and Sastry, 1994).

When leaf, stem and root extracts of C. pennisetiformis were added in metallic ions containing growth medium, fungal biomass was declined more profoundly as compared to presence of metal ions alone. The C. pennnisetiformis is well-known for its antifungal potential against many fungi including Fusarium spp. (Javaid et al., 2006; Javaid and Naqvi, 2012). The existence of steroid compounds has previously been documented in different parts of Censchrus spp. (Singariya et al., 2012, 2014). Therefore, the presence of different bioactive steroid compounds could be speculated in C. pennnisetiformis as well that probably confer resistance against $F$. oxysporum. These compounds may serve as potential sites for binding of chromium ions from the aqueous 
Table 2 - Percentage of the decrease in fungal biomass due to separate and combined application of $\mathrm{Cr}(\mathrm{VI})$ and methanolic extracts of Cenchrus pennisetiformis

\begin{tabular}{|c|c|c|c|c|c|}
\hline Treatments & $\begin{array}{l}\mathrm{Cr} \text { (III) conc. } \\
\text { (ppm) }\end{array}$ & $\begin{array}{c}\text { Extract conc. } \\
(\%)\end{array}$ & $\begin{array}{c}\text { Decrease over } \\
\text { negative control } \\
(\%)\end{array}$ & $\begin{array}{c}\text { Decrease over } \\
\text { corresponding } \\
\text { methanolic extracts } \\
(\%)\end{array}$ & $\begin{array}{c}\text { Decrease over } \\
\text { corresponding metal } \\
\text { (alone) } \\
\text { concentration }(\%)\end{array}$ \\
\hline \multirow{8}{*}{$\mathrm{Cr}(\mathrm{VI})$} & 0 & 0 (-control) & - & - & - \\
\hline & 50 & 0 & 18 & - & - \\
\hline & 100 & 0 & 22 & - & - \\
\hline & 150 & 0 & 37 & - & - \\
\hline & 200 & 0 & 41 & - & - \\
\hline & 250 & 0 & 45 & - & - \\
\hline & 300 & 0 & 64 & - & - \\
\hline & 350 & 0 & 89 & - & - \\
\hline \multirow{16}{*}{ Leaf extract } & 0 & 5 & 12 & - & 12 \\
\hline & 50 & 5 & 24 & 13 & 7 \\
\hline & 100 & 5 & 30 & 20 & 10 \\
\hline & 150 & 5 & 36 & 28 & -0.7 \\
\hline & 200 & 5 & 45 & 38 & 7 \\
\hline & 250 & 5 & 60 & 53 & 26 \\
\hline & 300 & 5 & 79 & 77 & 43 \\
\hline & 350 & 5 & 90 & 88 & 4 \\
\hline & 0 & 6 & 25 & - & 25 \\
\hline & 50 & 6 & 39 & 19 & 26 \\
\hline & 100 & 6 & 56 & 42 & 43 \\
\hline & 150 & 6 & 69 & 59 & 52 \\
\hline & 200 & 6 & 85 & 81 & 74 \\
\hline & 250 & 6 & 89 & 85 & 79 \\
\hline & 300 & 6 & 95 & 93 & 85 \\
\hline & 350 & 6 & 99 & 98 & 92 \\
\hline \multirow{16}{*}{ Stem extract } & $\overline{0}$ & 5 & 14 & - & 14 \\
\hline & 50 & 5 & 23 & 11 & 6 \\
\hline & 100 & 5 & 24 & 12 & 2 \\
\hline & 150 & 5 & 36 & 21 & -8 \\
\hline & 200 & 5 & 41 & 32 & -0.8 \\
\hline & 250 & 5 & 59 & 53 & 26 \\
\hline & 300 & 5 & 72 & 68 & 22 \\
\hline & 350 & 5 & 86 & 84 & -33 \\
\hline & 0 & 6 & 22 & - & 23 \\
\hline & 50 & 6 & 36 & 18 & 23 \\
\hline & 100 & 6 & 40 & 23 & 24 \\
\hline & 150 & 6 & 69 & 46 & 34 \\
\hline & 200 & 6 & 77 & 70 & 60 \\
\hline & 250 & 6 & 85 & 81 & 73 \\
\hline & 300 & 6 & 90 & 86 & 71 \\
\hline & 350 & 6 & 94 & 98 & 45 \\
\hline \multirow{16}{*}{ Root extract } & 0 & 5 & 45 & - & 45 \\
\hline & 50 & 5 & 57 & 20 & 48 \\
\hline & 100 & 5 & 66 & 37 & 56 \\
\hline & 150 & 5 & 71 & 47 & 53 \\
\hline & 200 & 5 & 81 & 65 & 67 \\
\hline & 250 & 5 & 87 & 76 & 76 \\
\hline & 300 & 5 & 94 & 88 & 83 \\
\hline & 350 & 5 & 99 & 98 & 92 \\
\hline & 0 & 6 & 50 & - & 50 \\
\hline & 50 & 6 & 65 & 30 & 58 \\
\hline & 100 & 6 & 70 & 40 & 61 \\
\hline & 150 & 6 & 78 & 56 & 64 \\
\hline & 200 & 6 & 87 & 74 & 78 \\
\hline & 250 & 6 & 93 & 86 & 88 \\
\hline & 300 & 6 & 95 & 90 & 86 \\
\hline & 350 & 6 & 100 & 99 & 95 \\
\hline
\end{tabular}

- Sign indicates increase in fungal biomass. 
solution, therefore may help in reducing metal toxicity in the soil. Nazir et al. (2011) reported significant accumulation of different heavy metal in root of $C$. pennisetiformis growing in industrial contaminated areas. The highest fungicidal potential of methanolic root might be related with occurrence of diversity of sterols, such as cycloergost, phytol and $\beta$-tocopherol in root extract of different Cenchrus spp. (Singariya et al., 2012).

The present study concludes that both $\mathrm{Cr}(\mathrm{III})$ and $\mathrm{Cr}(\mathrm{VI})$ ions, especially in high concentrations (150-350 ppm), are toxic to the $F$. oxysporum f. sp. lycopersici growth. Their toxic effects on the fungal growth were significantly enhanced when these ions are present in combination with root extract of C. pennnisetiformis.

\section{ACKNOWLEDGEMENTS}

The University of the Punjab, Lahore, Pakistan, which provided funding that was essential to the success of this project.

\section{REFERENCES}

Abdel-Monaim M.F. Induced systemic resistance in tomato plants against Fusarium wilt diseases. Int Res J Microbiol. 2012;3:14-23.

Amatussalam A., Abubacker M.N., Rajendran R.B. In situ Carica papaya stem matrix and Fusarium oxysporum (NCBT-156) mediated bioremediation of chromium. Indian J Exp Biol. 2011;49:925-31.

Anahid S., Yaghmaei S., Ghobadinejad Z. Heavy metal tolerance of fungi. Sci Iran., 2011;18:502-8.

Cardenas-Gonzalez J.F., Acosta-Rodriguez I. Hexavalent chromium removal by a Paecilomyces sp. fungal strain isolated from environment. Bioinorg Chem Appl.

2010;6:133-150.

Chandra A., Dubey A. Identification of species-specific RAPD markers in genus Cenchrus. J Environ Biol. 2010;31:403-7.

Hall T.J. Cloncurry buffel grass (Cenchrus pennisetiformis) in north-western Queensland. Trop Gras. 1978;12:10-19.

Hasan H.A.H. Role of rock phosphate in alleviation of heavy metals stress on Fusarium oxysporum. Plant Soil Environ. 2007;53:1-6.

Planta Daninha, Viçosa-MG, v. 34, n. 3, p. 453-463, 2016
Ignjatov M, Miloševiæ D., Nikoliæ Z. Gvozdanoviæ-Varga J, Jovièiæ D, Zdjelar G. Fusarium oxysporum as causal agent of tomato wilt and fruit rot. Pestic Phytomed. 2012;27:25-31.

Iqbal D., Javaid A. Bioassays guided fractionation of Coronopus didymus for its antifungal activity against Sclerotium rolfsii. Nat Prod Res. 2012;26:1638-44.

Iqbal M.A., Chaudhary M.N., Zaib S., Imran M., Ali K., Iqbal A. Accumulation of heavy metals $(\mathrm{Ni}, \mathrm{Cu}, \mathrm{Cd}, \mathrm{Cr}, \mathrm{Pb})$ in agricultural soils and spring seasonal plants irrigated by industrial wastewater. J Environ Technol Manage. 2011;2:89-97.

Javaid A., Naqvi S.F. Evaluation of antifungal potential of Cenchrus pennisetiformis for the management of Macrophomina phaseolina. World Acad Sci Eng Technol. 2012;69:832-5.

Javaid A., Rauf S. Management of basal rot disease of onion with dry leaf biomass of Chenopodium album as soil amendment. Int J Agric Biol. 2015; 17:142-8.

Javaid A., Naqvi S.F., Shoaib A. Antifungal activity of methanolic extracts of Sorghum halepense against Macrophomina phaseolina. Afr J Microbiol Res. 2012;6:5814-8.

Javaid A., Saddique A. Control of charcoal rot fungus Macrophomina phaseolina by extracts of Datura metel. Nat Prod Res. 2012;26:1715-20.

Javaid A., Anjum T., Bajwa R. Chemical control of Parthenium hysterophorus L. Int J Biol Biotechnol. 2006;3:387-90.

Jaworska M., Gorczyca A. Effect of metal ions on entomopathogenic fungi pathogenicity. Chem Inz Ekol. 2004;11:327.

Kurshied S., Shoaib A., Javaid A. In vitro toxicity evaluation of culture filtrates of Fusarium oxysporum f. sp. lycopersici to growth and physiology of tomato under chromium(VI) stress. J Anim Plant Sci. 2014;24:1241-5.

Kumar K.R. et al. Enhanced growth promotion of tomato and nutrient uptake by plant growth promoting rhizobacterial isolates in presence of tobacco mosaic virus pathogen.

Karnataka J Agric Sci. 2008;21:309-11.

Nazina T.N. et al. Phylogenetic diversity of aerobic saprotrophic bacteria isolated from daqing oil field. Microbiol. 2002;71:91-7.

Nazir A. et al. Hyperaccumulators of heavy metals of industrial areas of Islamabad and Rawalpindi. Pak J Bot. 2011;43:1925-33. 
Nelson P.E., Toussoun T.A., Cook R.J. Fusarium: diseases, biology and taxonomy. University Park: The Pennsylvania State University Press, 1981.

Prasad M., Garg A. Maheshwari R. Decontamination of polluted water employing bioremediation processes: A

Review. Int J Life Sci Biotechnol Pharm Res. 2012;1:1121.

Ramana V.V., Sastry S. Chromium toxicity in Neurospora crassa. J Inorg Biochem. 1994;56:87-95.

Raspor P. et al. The involvement of ATP sulfurylase in Se(VI) and $\mathrm{Cr}(\mathrm{VI})$ reduction processes in the fission yeast Schizosaccharomyces pombe. Appl Microbiol Biotechnol. 2003;63:89-95.

Shafique S., Shafique S., Bajwa R. Antifungal activity of allelopathic plant extracts $\mathrm{V}$ : Inhibition in biomass production of Fusarium solani by aqueous extracts of allelopathic grasses. Mycopath. 2004;2:83-6.
Sharma D.C., Sharma C.P., Tripathi R.D. Phytotoxic lesions of chromium in maize. Chemosphere. 2003;51:63-8.

Singariya P., Mourya KK., Kumar P. In vitro studies of antimicrobial activity of crude extracts of the Indian grasses Dhaman (Cenchrus ciliaris) and Kala-Dhaman (Cenchrus setigerus). Indian J Pharm Sci. 2012;74:261-5.

Singariya P., Kumar P., Mourya K.K. Isolation of new steroids of kala dhaman grass (Cenchrus setigerus) and evaluation of their bioactivity. Braz Arch Biol Technol. 2014;57:62-9.

Smith W.A. et al. Effect of carbon and energy source on bacterial chromate reduction. Biorem J. 2002;6:205-15.

Tkaczuk C. The effect of selected heavy metal ions on the growth and conidial germination of the aphid pathogenic fungus Pandora neoaphidis (Remaudiére et Hennebert) Humbe. Pol J Environ Stud. 2005; 14:897-902. 